\title{
CORRESPONDENCE
}

The Editor,

Journal of Glaciology

SIR,

\section{Early descriptions of pro-talus ramparts}

I refer to the correspondence in Journal of Glaciology, Vol. 33, No. 114, involving Butler, Porter, and Ballantyne, concerning the scientific primacy of the recognition of the pro-talus rampart as a (moderately) distinct land form. Like Porter, I think that the description by Drew (1873) of forms in the upper Indus, which was taken up by Ward (1873) to explain fossil features in the English Lake District, should be accorded primacy.

These descriptions are both part of much more general regional accounts, so it would be a pity to let this correspondence close without drawing attention to a little known paper by Kendall (1893) which is entirely devoted to a detailed description of such a form. Both the title of the work, "On a moraine-like mound near Snowdon", and the following quotation:

"at the close of the Glacial Epoch, when the Welsh glaciers had entirely passed away, there would be perennial snow banks in a thousand such sheltered corners. The nearer to the time of the great severity the more considerable would the snow banks be. Suppose now, we imagine a huge snow wreath banked up against the cliffs of $\mathrm{Cwm} \mathrm{Du}$. The weather would attack the lofty scarps, water would percolate between the columns of lava, and, freezing, force them upward, so that the stone showers so familiar to Alpine travellers would be produced here under conditions highly favourable to their development; but when the stones come down they would find the base of the cliffs pre-occupied by a talus of snow, therefore they would roll further out from the base and form a fringe of rock debris"

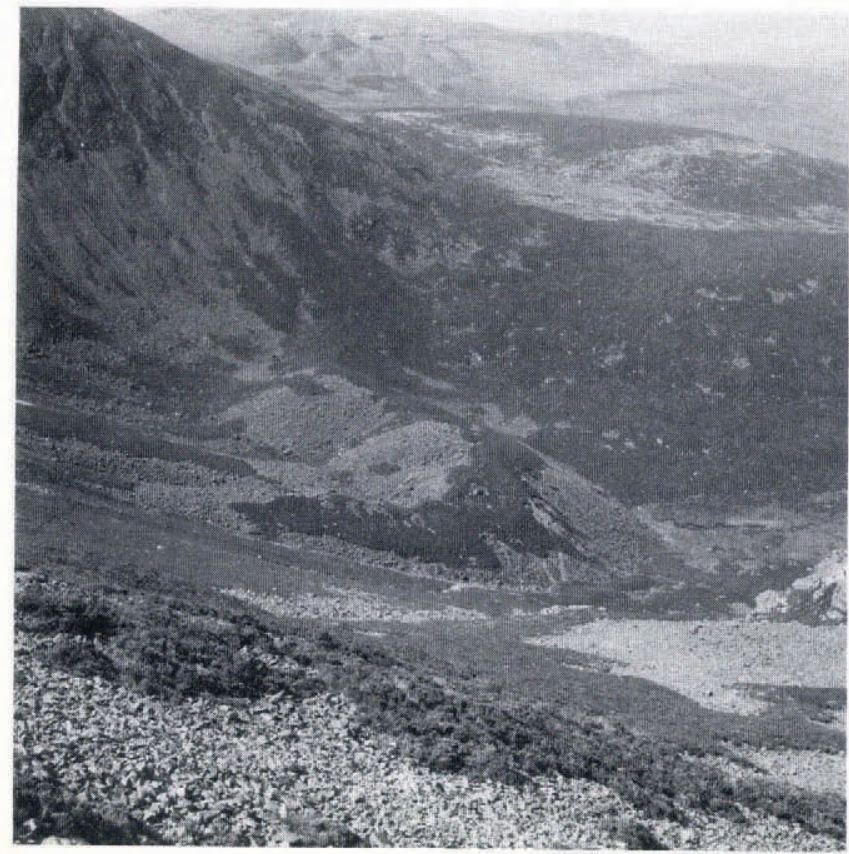

Fig. 1. The pro-talus rampart in Cwm Du, Snowdonia, North Wales. gives little doubt what Kendall had in mind.

The photograph (Fig. 1), taken in the mid 1960s, shows the feature which is at grid reference (OS) SH 536553. Since Kendall's visit, the site has been mapped by myself (Unwin, 1975, fig. 2) and more recently still by Gray (1982) who puts it into its regional and chronological context.

Department of Geography,

University of Leicester.

DAvid J. UnWIN

Leicester $L E I 7 R H$,

England

16 September 1987

\section{REFERENCES}

Drew, F. 1873. Alluvial and lacustrine deposits and glacial records of the Upper-Indus basin. Quarterly Journal of the Geological Society of London, 29, 441-71.

Gray, J.M. 1982. The last glaciers (Loch Lomond readvance) in Snowdonia, N. Wales. Geological Journal, 17, 111-33.

Kendall, P.F. 1893. On a moraine-like mound near Snowdon. Glacialist Magazine, 1, 68-70.

Unwin, D.J. 1975. The nature and origin of the corrie moraines of Snowdonia. Cambria, 2(1), 20-33.

Ward, C. 1873. The glaciation of the northern part of the Lake District. Quarterly Journal of the Geological Society of London, 29, 422-41.

SIR,

\section{Early descriptions of pro-talus ramparts}

Recent correspondence in the Journal of Glaciology concerning early descriptions of pro-talus ramparts (Butler, 1986, 1987; Ballantyne, 1987; Porter, 1987) has failed to include mention of an interesting account of these features, and their mode of formation, from Ireland (Kinahan, 1894). There are few detailed descriptions of pro-talus ramparts in Ireland and consequently Kinahan's paper, while being known to Irish glacial and periglacial geomorphologists as an early and important contribution to the subject (Warren, 1979; Lewis, 1985), is probably unknown beyond these shores.

Although Kinahan's report was published 21 years after those by Drew (1873) and Ward (1873), he had identified

"some forty years ago ... peculiar accumulations evidently in some way due to ice or its adjuncts".

He originally attributed these features to

"the Glacial period; while knowledge since gained would seem to prove that these terminal moraines may possibly be accumulating at the present day".

Despite naming such features "terminal moraines", Kinahan's account of their formation clearly indicates that the debris travelled across the surface of an inclined snow bed

"In the cooms and under the high cliffs great snow drifts accumulated .... . As is always the case after a severe frost, blocks and other detritus are displaced by falls when the thaw comes on; and if the fall is from a cliff over one of these drifts, the blocks and other stuff slide over it and form round its edge a terminal moraine". 
In addition to the use of "terminal moraine" to describe these deposits, Kinahan referred to one particular feature as

"a massive esker-like high accumulation of shingle".

While this terminology is perhaps unfortunate, the features he identified as resulting from this process are undoubtedly those we now call pro-talus ramparts.

Kinahan recognized these land forms in Counties Cork, Donegal, Galway, Mayo, Wexford, and Wicklow, and named specific locations where the process of debris accumulation could be observed during severe winters. He also brought to the attention of the scientific community the local term for such debris accumulations - cloghsnatty (correctly clogha snachta; Warren, 1979) or snow stones, which implies that their mode of formation was well understood long before the scientific study of glacial and periglacial phenomena had become established. Sadly, clogha snachta was not adopted by the scientific literature as were the Gaelic terms eiscir (esker) and druim (drumlin).

Finally, Kinahan's observations of clogha snachta were not confined to Ireland. He provided a brief description of a visit to the Canadian Rockies and, although

"My visit ... was so short that my conclusions can scarcely be of much value ... it was long enough to explain points in the Irish drift phenomena previously inexplicable".

Department of Environmental Studies

Peter Wilson

University of Ulster at Coleraine,

Cromore Road,

Coleraine,

Co. Londonderry BT52 ISA,

Northern Ireland

\section{December 1987}

\section{REFERENCES}

Ballantyne, C.K. 1987. Winter-talus ridges, nivation ridges, and pro-talus ramparts. Journal of Glaciology, 33(114), 246-47.

Butler, D.R. 1986. Winter-talus ridges, nivation ridges, and pro-talus ramparts. Journal of Glaciology, 32(112), 543.

Butler, D.R. 1987. Concerning early descriptions of pro-talus ramparts. Journal of Glaciology, 33(114), 248-49.

Drew, F. 1873. Alluvial and lacustrine deposits and glacial records of the Upper-Indus Basin. Quarterly Journal of the Geological Society of London, 29, 441-71.

Kinahan, G.H. 1894. The recent Irish glaciers. Irish Naturalist, 3, 236-40.

Lewis, C.A. 1985. Periglacial features. In Edwards, K.J., and Warren, W.P., eds. The Quaternary history of Ireland. London, Academic Press, 95-113.

Porter, S.C. 1987. Early description of pro-talus ramparts. Journal of Glaciology, 33(114), 247-48.

Ward, C. 1873. The glaciation of the northern part of the Lake District. Quarterly Journal of the Geological Society of London, 29, 422-41.

Warren, W.P. 1979. Moraines on the northern slopes and foothills of the Macgillycuddy's Reeks, south-west Ireland. In Schlüchter, C., ed. Moraines and varves. Rotterdam, A.A. Balkema, 223-36.

SIR,

\section{Terminus of Glaciar O'Higgins, southern Chile}

Glaciologists have been delighted by the synoptic views of glacier regions that satellite-borne imaging systems have made possible during the past two decades. Landsats 1, 2, and 3, for example, provide systematic coverage of many major glacier areas, and the U.S.S.R. Salyut and U.S. Space Shuttle programs offer less systematic, but higher resolution, coverage of many of the same areas (Williams, 1987). There have been many experiments that have made use of satellite data and observations. Although some of the research has produced interesting results, as is commonly the case with new methods, some of the interpretations of satellite data may be erroneous. This brief note gives an alternative interpretation for an event in South America that was recorded during the Salyut program.

The southern Patagonian ice field has several dynamic outlet glaciers, but the region has been much less studied than comparable glacier regions in North America. The satellite-borne systems have acquired the only readily available data for some of the Patagonian glaciers. Glebova and others (1981) and later Denisov and others (1987) reported on Salyut observations on Glaciar O'Higgins and cited a recession of $12 \mathrm{~km}^{2}$ between 22 and 30 December 1977, when a large tabular iceberg calved off. Because Glaciar O'Higgins is about $2 \mathrm{~km}$ wide, the linear recession would have been about $6 \mathrm{~km}$.

Landsat images from 25 February 1976 (2399-13410) and 8 March 1979 (30368-13450-D) show that the glacier had a net recession of about $0.5 \mathrm{~km}$ during that 3 year interval. Denisov and others (1987) showed the glacier terminus, after the calving event, to be at about the 1976 and 1979 positions. The Denisov and others (1987) interpretation, that a calving event eliminated $12 \mathrm{~km}^{2}$ of the glacier, would have required a $6 \mathrm{~km}$ advance over the scant 2 years from February 1976 to December 1977. Such an advance would have required an average speed of $9 \mathrm{~m} / \mathrm{d}$, assuming no calving. If there had been calving, which is very likely, the average speed required would have been even greater. I am not aware of any calving glacier that has made such a rapid advance.

I suggest that the event Denisov and others (1987) call a calving event of the glacier terminus was, in reality, the break-up of a mass of floating, freeze-welded lake ice, brash ice, and icebergs. A similar mass forms at the fjord head in front of calving glaciers in Alaska during winter and spring, and breaks up in late spring. A similar situation could likely occur in front of Glaciar O'Higgins in the southern winter and spring. The floating mass of lake ice, brash ice, and icebergs would be spectrally similar to the ice of the glacier, and could be easily confused with part of the glacier at spatial resolutions of $30-100 \mathrm{~m}$. This heterogeneous mass of floating ice is dynamically different from either floating or grounded glacier ice, and it is important that a distinction be made when referring to the position of the glacier terminus.

U.S. Geological Survey,

ROBERT M. KRIMMEL

Tacoma,

Washington 98402, U.S.A.

13 November 1987

\section{REFERENCES}

Denisov, L.V., Nosenko, G.A., Grechko, G.M., Ivanchenko, A.S., and Kotlyakov, V.M. 1987. Glaciological studies and experiments from the Salyut-6 orbital space station. Polar Geography and Geology, 11(1), 12-24.

Glebova, L.N., Koryakin, V.S., and Loseva, I.A. 1981. Morfologicheskaya kharakteristika Yuzhnogo Patagonskogo lednikovogo plato [Morphological characteristics of the Hielo Patagonico Sur]. Materialy Glyatsiologicheskikh Issledovaniy. Khronika. Obsuzhdeniya, 42, 48-57.

Williams, R.S., jr. 1987. Background to the Soviet glaciological studies from the Salyut-6 orbital space station. Polar Geography and Geology, 11(1), 1-11.

\section{ERRATUM}

Vol. 33, No. 115 , p. 308 , Fig. 12

Unfortunately, this illustration has been reproduced incorrectly. It should have appeared, reversed left to right, and inverted top to bottom. 